\title{
愛知県と岐阜県に集団を分割したデュロック種の系統開発
}

\author{
吉岡 豪 1 ·河合恒鿆 1 . 今枝紀明 1 ・鳥本安男 1 \\ 栗田隆行 $2 \cdot$ 田島茂行 $2 \cdot$ 安藤康紀 $2 \cdot$ 鹿田講基 2 \\ 1 岐阜県畜産研究所 養豚研究部、2 愛知県農業総合試験場 畜産研究部 豚グループ
}

\section{The breeding improvement of Duroc line in a closed herd divided into Aichi and Gifu prefecture}

Gou YOSHIOKA ${ }^{1}$, Kousuke KAWAI ${ }^{1}$, Noriaki IMAEDA ${ }^{1}$, Yasuo TORIMOTO ${ }^{1}$,
Takayuki KURITA ${ }^{2}$, Shigeyuki TAJIMA ${ }^{2}$, Yasunori ANDO ${ }^{2}$, Kouki SHIKADA ${ }^{2}$

${ }^{1}$ Swine Research Department, Gifu Prefectural Livestock Reseach Institute

2 Animal Husbandry Research Institute, Aichi Agricultural Research Center

\section{1.はじめに}

我が国における豚の系統造成は、昭和 45、46 年に 8 県の畜産試験場で開始されたのを皮切りに、これまで 多くの畜産研究機関によって行われてきた（阿部、 1962)。豚の系統は、主に産肉能力、若しくは繁殖能 力といった生産性に影響を及ぼす形質が改良された、 遺伝的な能力が似通った集団である。よって生産者は、 それぞれの系統豚の能力を把握し、利用することによ り、それまでの単純な品種間交配に比べ、より斉一性 のある優れた肉豚生産が可能となった。

近年、国内に扮ける養豚経営を取り巻く現況は厳し い。よって、国産豚肉のシェアを維持・拡大するため には、輸入豚肉に対抗出来る生産基盤の確立、とりわ け種豚の改良が必要であるといえる。

これまで愛知県では 4 つ系統豚を造成しており、 最近では平成 8 年度にランドレース種系統豚の「アイ リス L2」を、平成 15 年度に大ヨークシャー種系統豚 を造成した。また岐阜県では、平成 5 年度に大ヨーク シャー種系統豚「ナガラヨーク」を開発し、それぞれ の県内で普及している。さらに、両県ともに雄系系統 豚は、昭和 60 年度に家畜改良センターが造成したデ ユロック種 (以下、 D種という。) 系統豚「サクラ 201」 を長年に渡って県内農家に分譲してきた。しかし最近 では、「サクラ $201 」 の$ 発育遅延や肢蹄不良の出現頻度 が増加し、その対応に迫られていた。しかし、两県と もに単独で新規系統を開発するスペースやマンパワー 不足によって対応出来なかった。

そこで我々は、これらの問題点を解消し、安定的な 生産基盤の確立のため、平成 12 年度に造成集団を愛
知県と岐阜県に分割した新規 D 種系統開発を開始し た。

\section{2. 基礎豚の導入計画}

基礎豚の導入予定頭数は、愛知県が雄 6 頭、雌 34 頭、岐皁県が雄 4 頭、雌 16 頭の合計、雄 10 頭、雌 50 頭とした。導入先は、愛知県の雌 34 頭の内、10 頭を 愛知県が系統を維持している「サクラ $201 」$ とする以外 はすべて米国の農場からとした。導入先のほとんどを 米国に依存した理由は、正確な検定が行われている事、 能力が高い個体が存在する事、疾病管理が適切である 事が挙げられる。疾病については、国外からの導入た め、輸入検疫、次いで着地検疫を行う事から、厳重な チェックが脚かる事も有用な点である。

導入種畜の選定基準は、以下の通りとした。

$<$ 肢蹄・体型 $>$

*肢蹄 (強健)の良いもの

（爪が大きく、揃いがょく、歩様のなめらかな もの)

*体型は太く深みがあるもの

*骨量が多いもの

$<$ 産肉能力 $>$

* $105 \mathrm{~kg}$ 到達日齢は、 150 日以内 $(700 \mathrm{~g} / \mathrm{day})$

*背脂肪厚は、 $1.4 \sim 2.0(\mathrm{~cm})$ 以内

*ロース断面積は、 $45.0\left(\mathrm{~cm}^{2}\right)$ 以上

\section{3. 導入豚の成績}

導入豚の直接検定成績を表 1 に示した。 導入豚は、雌の一日平均増体重 (以下、DG とする。) 
表 1 . 導入豚の直接検定成績

\begin{tabular}{rlcc}
\hline & & 雄 $(\mathrm{n}=11)^{1)}$ & 雌 $(\mathrm{n}=41)^{2)}$ \\
\hline 一日平均増体重 & $(\mathrm{g} /$ day $)$ & $702 \pm 43$ & $672 \pm 48$ \\
背脂肪 & $(\mathrm{cm})$ & $1.45 \pm 0.28$ & $1.52 \pm 0.19$ \\
ロース芯断面積 & $\left(\mathrm{cm}^{2}\right)$ & $47.4 \pm 5.26$ & $45.3 \pm 3.94$ \\
\hline
\end{tabular}

1) 愛知県 6 頭、岐皁県 5 頭

2) 愛知県 24 頭、岐阜県 17 頭

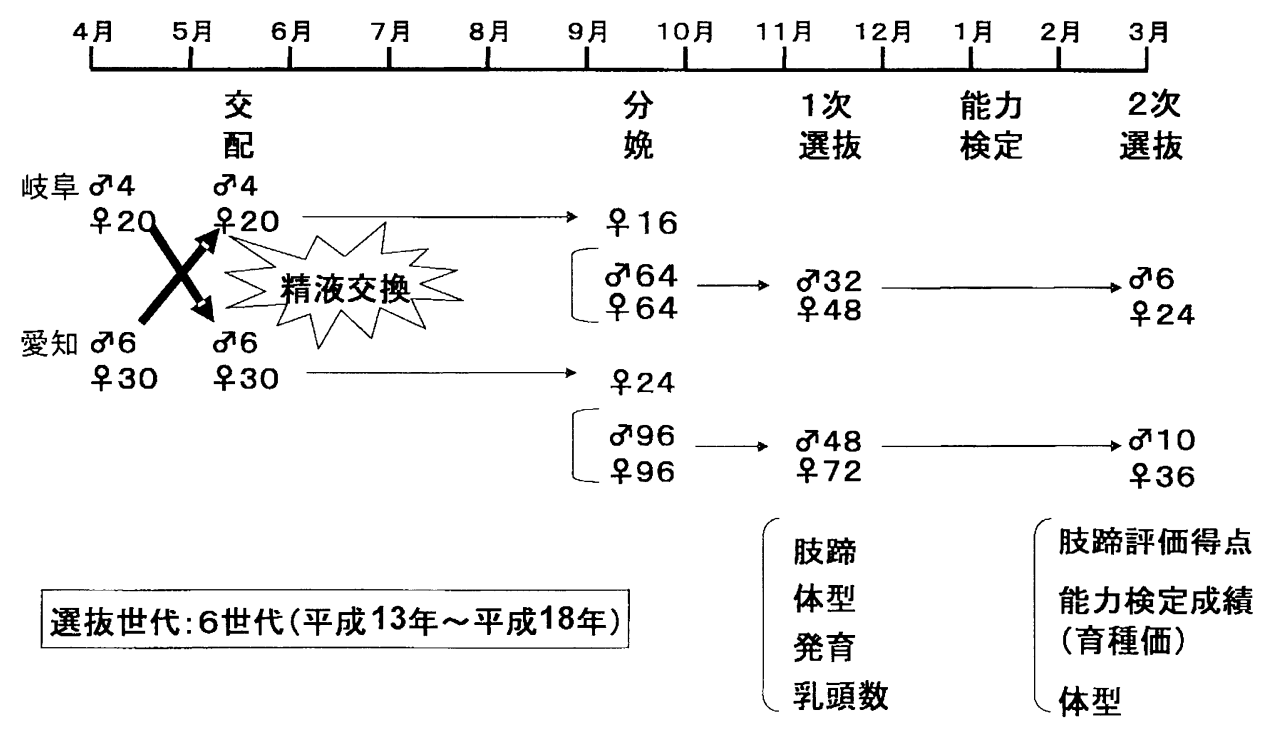

図 1. 造成集団を分割した新規デュロック種系統開発の基本計画

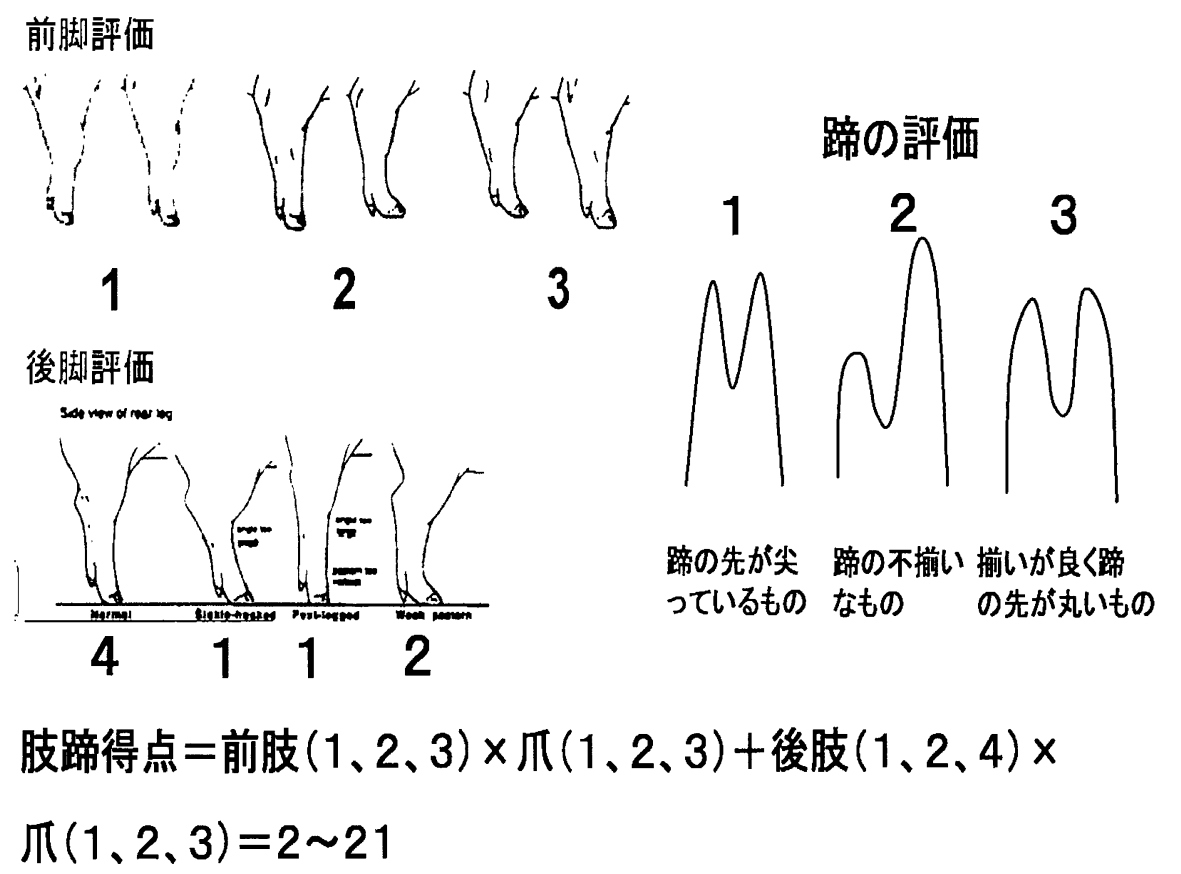

図 2. 肢蹄の評価方法 
が平均で $672(\mathrm{~g} / \mathrm{day})$ であり、選定基準を下回った。そ の他の形質は、すべて選定基準を満たした。

\section{4. 選抜方法及び改良目標（基本計画）}

選抜方法 (基本計画)の概要を図 1 に示した。 交配は原則として人工授精とし、育種集団の基盤の 構築と場所間差の推定を行うため、第 2 世代目までは 積極的に各々の県が繋養している種雄豚の精液の交換 を行い、血縁の架橋を構築することとした。改良する 形質は、DG、体長 2 分の 1 部位の背脂肪の厚さ (以下、 BF とする。)、およびロース芯断面積 (以下、EM とす る。とした。以上の 3 形質に加えて、種豚として重要 な肢蹄及び体型は、独立淘汰によって選抜することと した。個体の選抜方法は、1 次段階として、離乳時に 肢蹄、体型、発育、乳頭数が不良な個体を排除する程 度の軽い選抜を行い、各々の腹から雄 2 頭、雌 $2 \sim 3$ 頭程度を選抜した。次いで、体重が $105 \mathrm{~kg}$ に到達した 時点で 2 次選抜を行うこととした。第 1 亿 世代は、 前述したとおり育種集団の基盤の構築と場所間差の推 定が主な目的であるため、2 次選抜は肢蹄および体型 の評価値を用い、基礎集団の血液が絶えることが無い ように選抜するものとした。特に肢蹄については、図 2 に示した米国の National Swine Improvement Federation が提示している肢蹄評価基準を一部改良し た評価方法により個体毎の評価を行い、評価者が異な っても一定の評価が行えるように配虑した。第 3 世代 以降は、肢蹄及び体型の独立淘汰に加え、積極的に産 肉能力の改良を推進するため第 1 ～世代で得られた 直接検定結果を用い、DG、BF、EMの育種価の最良 線形不偏子測值を推定し選抜することとした。

\section{5. 造成集団を分割した系統開発の問題点(第 1 世代 の検定結果から)}

第 1 世代の直接検定の結果、DG は、愛知県の雄 $(\mathrm{n}=55)$ が $885 \pm 78(\mathrm{~g} / \mathrm{day}) 、$ 岐阜県の雄 $(\mathrm{n}=38)$ が 932 \pm 102 となり、岐阜県の雄が高い結果が得られた。雌 は、愛知県 $(n=69)$ が、 $840 \pm 62(\mathrm{~g} / \mathrm{day}) 、$ 岐阜県 $(\mathrm{n}=$ 27) が、 $878 \pm 101$ (g/day) であった。雌の DG も雄と同 様に、岐阜県が高い結果であった。各県の集団間に血 縁が充分に架橋していないことから、場所の違いによ る影響を明確に判断することは出来ないが、DGに対 する場所の影響が異なる可能性が示唆された。

また、EMは、愛知県の雄が $43.5 \pm 3.2\left(\mathrm{~cm}^{2}\right)$ 、岐皁 県の雄が $39.0 \pm 2.3\left(\mathrm{~cm}^{2}\right)$ であり、雌では愛知県が、 $43.4 \pm 3.6\left(\mathrm{~cm}^{2}\right)$ 、岐阜県が、 $38.6 \pm 2.8\left(\mathrm{~cm}^{2}\right)$ であった。
雌雄ともに愛知県が岐阜県よりも、雄の平均で 4.5 $\left(\mathrm{cm}^{2}\right)$ 、雌の平均で $4.8\left(\mathrm{~cm}^{2}\right)$ 大きかった。さらに $\mathrm{BF}$ は、愛知県の雄が $1.41 \pm 0.20(\mathrm{~cm})$ 、岐皁県の雄が 1.18 $\pm 0.14(\mathrm{~cm})$ 、雌では愛知県が、1.53 $\pm 0.24(\mathrm{~cm}) 、$ 岐阜 県が、 $1.32 \pm 0.24(\mathrm{~cm})$ であった。以上から、EM およ びBFでは、愛知県が岐阜県よりも大きく、厚い結果 が得られた。

$\mathrm{EM}$ と BF の測定值が県間で大きく異なる原因とし て、各々の県で導入した種雄の遺伝的能力と家畜生体 肉質測定装置が各々の県で異なることがあげられる。 しかし、基礎世代の種雄豚は偏りなく交配されている ため、遺伝的な要因の関与よりも、測定装置が各々の 県で異なることに起因している可能性が強いと考えら れた。

\section{6. 超音波家畜生体肉質診断装置の機種間差}

$\mathrm{G} 1$ 世代の BF 及び EM の測定結果が県間で大きく異 なる原因として機種間差に起因している可能性が示唆 された。そこで我々は、50頭の調查豚を用意し、それ ぞれの県で保持している機器の違いによる差異を調査 した。

図 3 にBFにおける機種間差を示した。機種間差を 明確にするため、A 機器 (カラースキャニングスコー プUSL12 型、(株) カイジョー社製; 愛知県) の測定結 果を昇順に並べて表示し、同一個体における B 機器 (スーパーアイミートSSD900、富士平工業 (株) 社 製; 岐阜県)の測定結果を示した。B機器での測定結 果は、A 機器よりも、お㧍むね厚い結果を示す場合が 多かったが、両測定值間の差は一定でなく、A 機器に 比べ、 $6.7(\mathrm{~mm})$ 厚く測定される個体も存在した。また、 それとは逆に $\mathrm{B}$ 機器の方が $\mathrm{A}$ 機器よりも薄く測定され る個体が 3 頭存在した。

図4にEMに打ける機種間差を示した。データの表 示方法は図 3 と同様とした。 $\mathrm{BF}$ の測定結果と異なり、 $\mathrm{B}$ 機器での測定結果は、A 機器よりもおおむね小さく 評価されたが、 BF の測定結果と同様に、ほぼ同様の 測定值が得られた個体が存在した反面、最も大きい測 定結果の差異で、A 機器では $47.5\left(\mathrm{~cm}^{2}\right)$ と評価された 個体が B 機器では $36.1\left(\mathrm{~cm}^{2}\right)$ と評価され、11.4 $\left(\mathrm{cm}^{2}\right)$ の違いが観察される個体があった。また、一部、B機 器の測定が $\mathrm{A}$ 機器の測定結果よりも大きく評価される 個体も存在した。

以上の結果から、BF及びEMの機器間における測 定結果の差異は大きく、一定の傾向を示さないことが 観察された。加えて、我々は同一機器での測定におい 


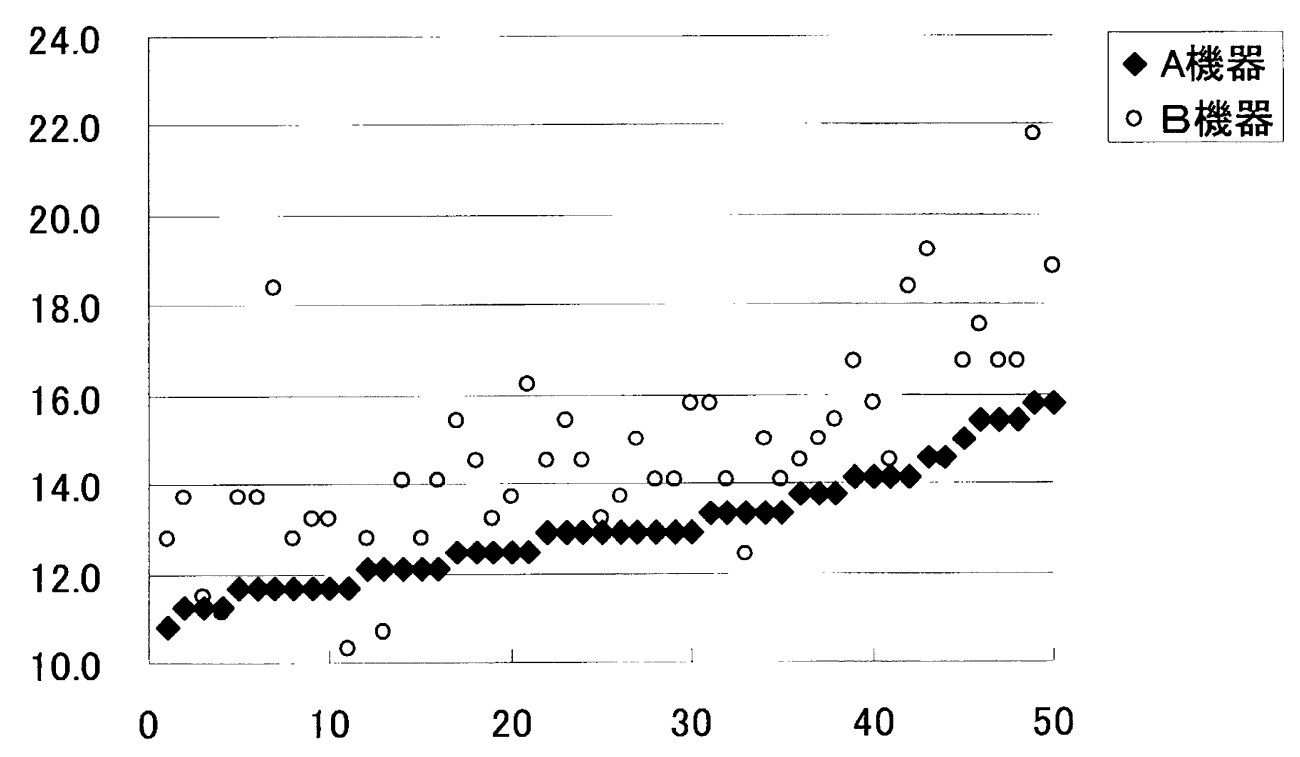

四 3. BFにおける機種間差

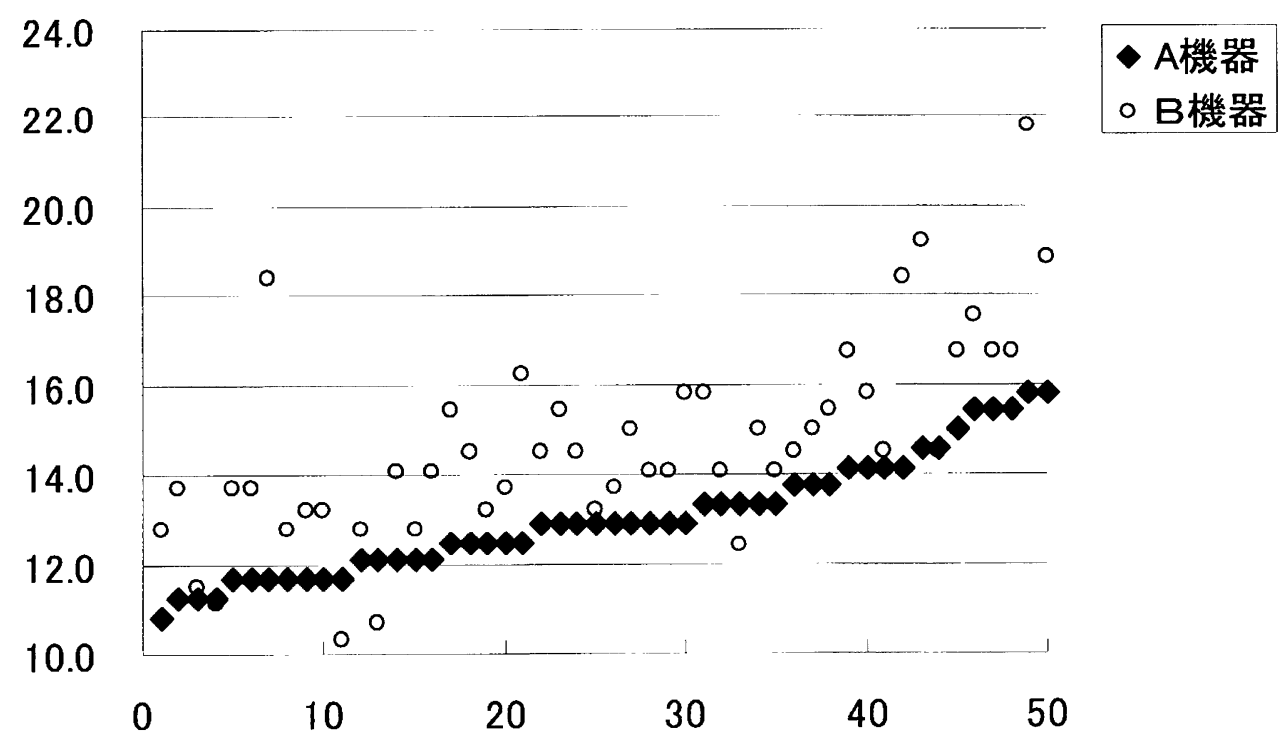

図4. EMにおける機種間差

ても測定者の間に大きな測定結果の差異が認められる ことも確認している。Herring ら (1994) は、44頭の去 勢牛の 12 番目と 13 番目の肋骨部位における背脂肪と 胸最長筋を、 3 人の測定技術者と 2 つ異なる家畜生 体肉質診断装置を用いて测定した結果、測定者及び測 定機器間の測定結果に違いが有り、適正な測定者と機 器を測定しなければ超音波による生体の評価は困難で あると報告している。これらのことから、より正確な $\mathrm{BF}$ 及び $\mathrm{EM}$ の測定を行うためには、家畜生体肉質測
定装置による測定值と枝肉の実測值との照合によるト レーニングを積んだ測定精度の高い測定者の育成と測 定機器及び測定者の統一が必要である。

\section{7. まとめ}

造成集団を分割した系統開発のメリットは、育種規 模の拡大、開発費用の大幅な節減、単独場所の系統開 発と同等の成果 (系統開発) がある。一方、実際に開発 に着手することにより、種豚の交流が困難、飼養条件 
を揃えにくい(飼養場所の影響が大きい)、形質の機器 間差と測定者間の誤差が大きいという問題点が判明し た。

今後、愛知県と岐阜県との協力によりこれらの問題 点を解決し、造成集団を分割した系統開発の手法確立 に多くの有効な情報を提供していきたい。

\section{引用文献}

阿部猛夫. 系統豚 Q \& A. 第 1 版. 20-21. 全国農業協同 組合連合会畜産資材部. 東京. 1962.

Herring WO, Miller DC, Bertrand JK, Benysheck LL. Evaluation of machine, technician, and interpreter effects on ultrasonic measures of backfat and longissimus muscle area in beef cattle. Journal of Animal Science, 72(9): 2216-2226. 1994. 